DOI https://doi.org/10.30525/978-9934-26-114-5-37

\title{
ПАРАДИГМАЛЬНІ ВИМІРИ ОСВІТИ В УКРАЇНІ: СВІТОВИЙ ДОСВІД І ВІТЧИЗНЯНА ПРАКТИКА
}

\author{
Квіткін П. В. \\ кандидат філософських наук, професор, \\ професор кафедри філософії \\ Харківський наиіональний університет Повітряних Сил \\ імені Івана Кожедуба \\ Дятлова I. B. \\ кандидат філософських наук, старший викладач кафедри філософії \\ Харківський національний університет Повітряних Сил \\ імені Івана Кожедуба \\ м. Харків, Україна
}

Еволюція системи міжнародних відносин і загострення боротьби за реалізацію національних стратегічних інтересів, процеси глобалізації і цивілізаційної ідентифікації народів, становлення інформаційного суспільства і розгортання інформаційного протиборства у сучасному світі, необхідність подолання і запобігання виникненню загроз i викликів світовому співтовариству, актуалізують проблему місця і ролі освіти у бутті сучасного соціуму.

Концептуальні положення щодо змісту і спрямованості сучасної освіти сформульовані у доповіді Міжнародної комісії з освіти для XXI століття «Освіта: прихований скарб» [2], у якій визначено чотири основних стовпи, на яких повинна базуватися освіта:

- навчитися пізнавати (вчитися) - поєднувати досить широку загальну культуру 3 можливістю поглибленої роботи з обмеженою кількістю дисциплін, уміння вчитися тому, що надає безперервна освіта;

- навчитися роботи - набути не лише професійну кваліфікацію, але й в більш широкому смислі компетентність, що надає можливість впоратися з різними чисельними ситуаціями і працювати у складі групи;

- навчитися жити разом - виховувати розуміння іншого і відчуття взаємозалежності, реалізовувати спільні проекти і бути готовим до врегулювання конфліктів в умовах плюралізму і поваги цінностей, взаєморозуміння світу;

- навчитися жити - сприяти розквіту власної особистості і бути здатним діяти, проявляти незалежність, самостійність суджень і особисту відповідальність. 
Становлення національної системи освіти в Україні цілком відповідало загальносвітовим тенденціям розвитку освіти. У чинній Державній національній програмі «Освіта» («Україна XXI століття») (1993) визначається, що вища освіта забезпечує фундаментальну наукову, загальнокультурну, практичну підготовку і спрямована на підготовку фахівців, що визначають темпи і рівень науково-технічного та соціального прогресу, сприяють утвердженню гуманістичних ідеалів, норм людського співжиття, формування інтелектуального потенціалу нації як найвищої цінності суспільства. Серед вихідних принципів реалізації Програми визначаються: пріоритетність освіти, демократизація освіти, гуманізація освіти, гуманітаризація освіти, національна спрямованість освіти, відкритість системи освіти, безперервність освіти, нероздільність навчання i виховання, багатоукладність та варіантність освіти [3].

Вихідні принципи реалізації Державної національної програми, насамперед акцентують увагу на проблемах гуманізації, гуманітаризації та виховній спрямованості функціонування системи освіти:

гуманізація освіти, що полягає в утвердженні людини як найвищої соціальної цінності, найповнішому розкритті ії здібностей та задоволенні різноманітних освітніх потреб, забезпеченні пріоритетності загальнолюдських цінностей, гармонії стосунків людини і навколишнього середовища, суспільства і природи;

- гуманітаризація освіти, що покликана формувати цілісну картину світу, духовність, культуру особистості і планетарне мислення;

- національна спрямованість освіти, що полягає у невіддільності освіти від національного грунту, ii органічному поєднанні 3 національною історією i народними традиціями, збереженні та збагаченні культури українського народу, визнанні освіти важливим інструментом національного розвитку i гармонізації національних відносин [3].

Відповідно до цього одним із стратегічних завдань реформування змісту освіти у Програмі визначено оптимальне поєднання гуманітарної i природничо-математичної складових освіти, теоретичних i практичних компонентів, класичної спадщини та сучасних досягнень наукової думки, органічний зв'язок з національною історією, культурою, традиціями [3]. Практичні шляхи реалізації Програми визначені у чинній постанові Кабінету Міністрів України «Про розроблення державних стандартів вищої освіти» (1998) [9]. За цією Постановою Освітньо-професійна програма повинна включати:

- цикли гуманітарної, соціально-економічної та природничонаукової підготовки, що забезпечує певний освітній рівень; 
- цикл професійної (професійно-орієнтованої) та практичної підготовки, що разом 3 попередніми циклами забезпечує певний освітньо-кваліфікаційний рівень.

Зазначені нормативно-правові акти створювали усі передумови для забезпечення реалізації у національній системі освіти концептуальних підходів і тенденцій розвитку світової освіти. Однак, 32014 року у національній системі освіти починає домінувати технократична парадигма вищої освіти, що знайшло своє відображення у наказі МОН України від 25.11.2014 № 1392 [7], яким визначена втрата чинності наказу МОН України від 09.07.2009 № 642 «Про організацію вивчення гуманітарних дисциплін за вільним вибором студента» [8]. На практиці було скасовано наказ, у якому визначався перелік не лише вибіркових, але й нормативних дисциплін гуманітарної та соціально-економічної підготовки бакалаврів.

Технократична парадигма національної освіти знайшла свій прояв у Методичних рекомендаціях щодо розроблення стандартів вищої освіти [6] та Стандартах вищої освіти [10]. Вища освіта має вибудовуватись на основі найновіших досягнень сучасної науки, насамперед, через фундаментальне засвоєння комплексу природничих і фізико-математичних дисциплін з одночасним проникненням у таємницю людського життя, осягненням основних цінностей людини і суспільства, нації і народу, що забезпечують гуманітарні науки, насамперед, історія, філософія, культурологія, економічна теорія, політологія тощо [1, с. 12].

Для забезпечення реалізації концептуальних положень щодо змісту і спрямованості сучасної освіти, положень закону України «Про освіту» (2017) про мету освіти - всебічний розвиток людини як особистості та найвищої цінності суспільства, іiі талантів, інтелектуальних, творчих і фізичних здібностей, формування цінностей і необхідних для успішної самореалізації компетентностей, виховання відповідальних громадян, які здатні до свідомого суспільного вибору та спрямування своєї діяльності на користь іншим людям і суспільству, збагачення на цій основі інтелектуального, економічного, творчого, культурного потенціалу українського народу, підвищення освітнього рівня громадян задля забезпечення сталого розвитку України та їі європейського вибору [4], насамперед вважається необхідним.

1. Розробити загальні стандарти вищої освіти (за відповідними рівнями), які повинні відображати компетентності i результати навчання, що відповідають рівню вищої освіти та є обов'язковими компонентами стандартів вищої освіти 3 усіх спеціальностей. Складовими загальних стандартів повинні стати: інтегральна компетентність, громадянські та соціальні компетентності, загальні компетентності, фахові компетентності спеціальності. 
2. Визначити перелік нормативних дисциплін гуманітарної, соціально-економічної та природничо-наукової підготовки, що забезпечують певний освітній рівень i формування відповідних громадянських і соціальних, загальних компетентностей.

\section{Література:}

1. Андрущенко В. Вища освіта у пост-болонському просторі: спроба прогностичного аналізу. Філософія освіти. 2005. № 2. С. 6-19.

2. Делор Ж. Образование: сокрытое сокровище: Основные положения Доклада Международной комиссии по образованию для XXI века. ЮНЕСКО, 1996. URL: https://www.ifap.ru/library/book201.pdf (дата обращения: 12.07.2021).

3. Державна національна програма «Освіта» («Україна XXI століття»). Затверджена Постановою Кабінету Міністрів України від 3 листопада 1993 р. № 896. (Із змінами, внесеними згідно з Постановою КМ № вid 29.05.96 ). URL: https://zakon.rada.gov.ua/ laws/show/896-93-\%D0\%BF\#Text (дата звернення: 12.07.2021).

4. Закон України Про освіту. URL: https://zakon.rada.gov.ua/ laws/show/2145-19\#Text (дата звернення: 12.07.2021).

5. Зразок освітньо-професійної програми. Додаток до листа $\mathrm{MOH}$ України від 28.04.2017 № 1/9-239. URL: https://pstu.edu (дата звернення: 12.07.2021).

6. Методичні рекомендації щодо розроблення стандартів вищої освіти. Наказ МОН України від 01.06.2017 № 600 (у редакції наказу MOH України від 21.12.2017 № 1648). URL: https://mon.gov.ua > 2020metod-rekomendacziyi (дата звернення: 12.07.2021).

7. Про визнання таким, що втратив чинність, наказу Міністерства освіти і науки України від 09.07.2009 № 642. Наказ МОН України від 25.11.2014 № 1392. URL: https://zakon.rada.gov.ua/rada/show/v139272914\#Tеxt (дата звернення: 12.07.2021).

8. Про організацію вивчення гуманітарних дисциплін за вільним вибором студента. Наказ MOH України від 09.07.2009 № 642. URL: https://zakon.rada.gov.ua/rada/show/v0642290-09\#Text (дата звернення: 12.07.2021).

9. Про розроблення державних стандартів вищої освіти. Постанова Кабінету Міністрів України від 7 серпня 1998 р. № 1247. URL: https://zakon.rada.gov.ua/laws/show/1247-98-\%D0\%BF\#Text (дата звернення: 12.07.2021).

10. Стандарти вищої освіти. URL: https://mon.gov.ua/ua/osvita/ visha-osvita/naukovo-metodichna-rada-ministerstva-osviti-i-nauki-

ukrayini/zatverdzheni-standarti-vishoyi-osviti (дата звернення: 12.07.2021). 